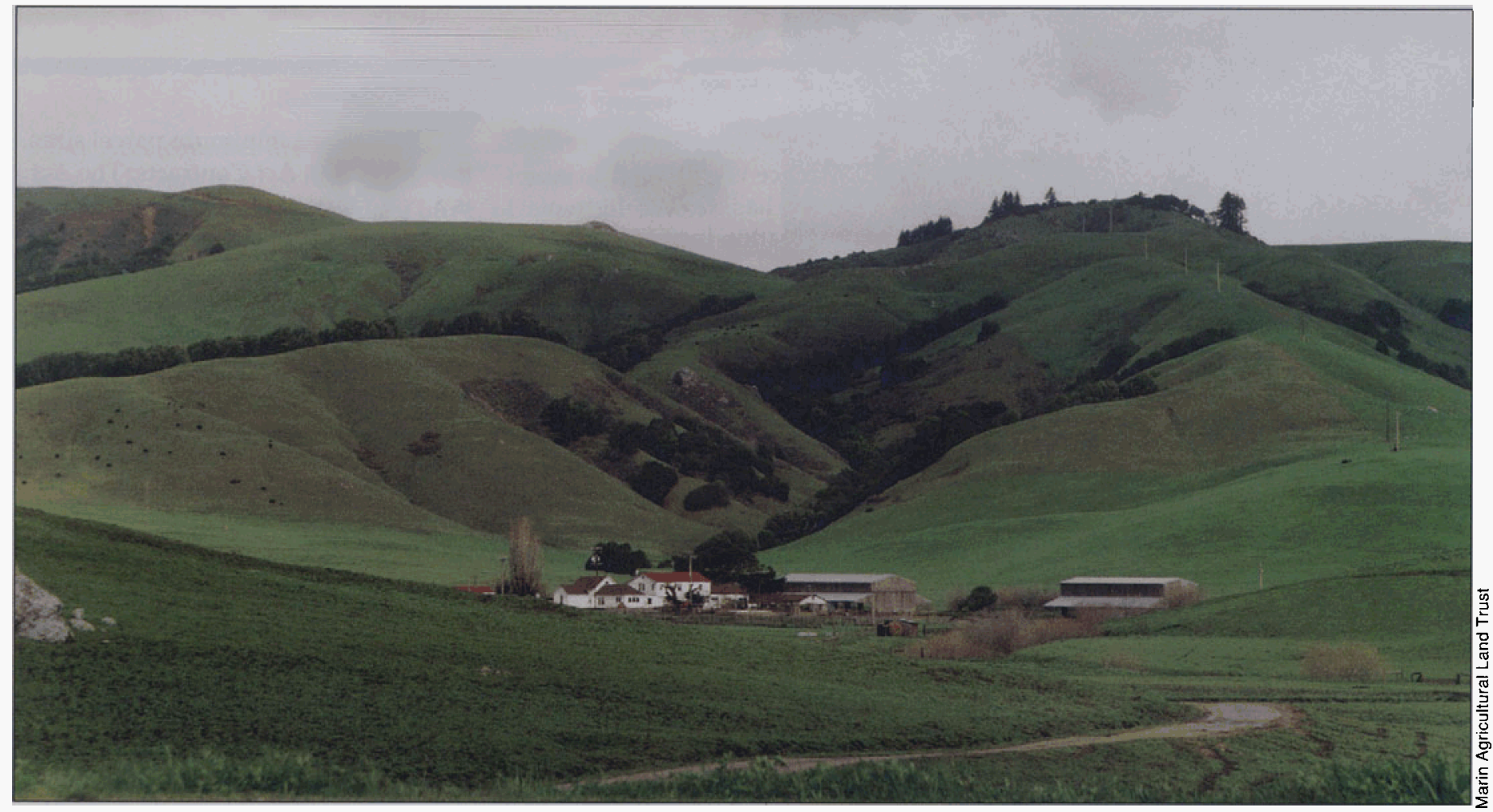

\title{
North Bay leads Central Valley in protecting farmland
}

\begin{abstract}
North Bay residents are more active than Central Valley residents in protecting their farmland. One reason may be that farmland in the North Bay (above) appears to be finite, with most of it contained within small, green valleys ringed by soft hills, whereas farmland in most of the Central Valley (below) seems to stretch endlessly.
\end{abstract}

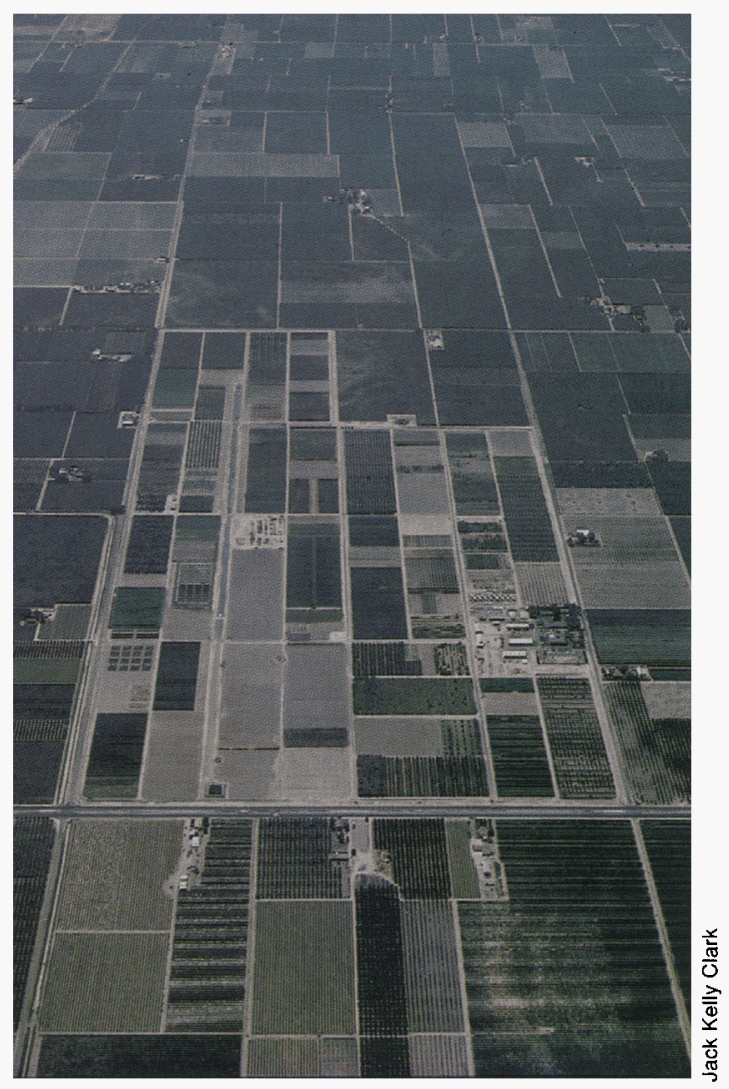

In a comparison of four counties in the San Francisco North Bay area with seven Central Valley counties, researchers found that the coastal jurisdictions are more aggressive in limiting the conversion of farmland to urban uses and preserving open space. The North Bay counties make more use of innovative programs - primarily the acquisition of conservation easements on farmland by nonprofit land trusts and local governments, but also the adoption of growth boundaries. Local political variations account for much of these regional policy differences. Especially notable is the greater mobilization of conservation coalitions, including the more extensive use of the ballot box to protect open space, in the North Bay than in the Central Valley.
$\mathrm{T}$ he 17-county Central Valley is the 1 most productive and diverse farming region in the world, growing more than 250 commodities. Stretching almost 400 miles from north to south, the Central Valley has 14.5 million acres of farmland and accounts for two-thirds of California's total agricultural market value, which was $\$ 24.5$ billion in 1996. By contrast, the ninecounty San Francisco Bay Area has only roughly one-seventh as many agricultural acres and generated only one-eighteenth as much in farm market value in 1995. Even so, a number of Bay Area counties are more active than the Central Valley jurisdictions, and they lead the state's efforts to protect farmland.

We compared four northern Bay Area counties (Marin, Napa, Solano and Sonoma) with seven Central Valley counties (Fresno, Kern, San Joaquin, Stanislaus, Sutter, Tulare and

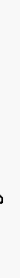




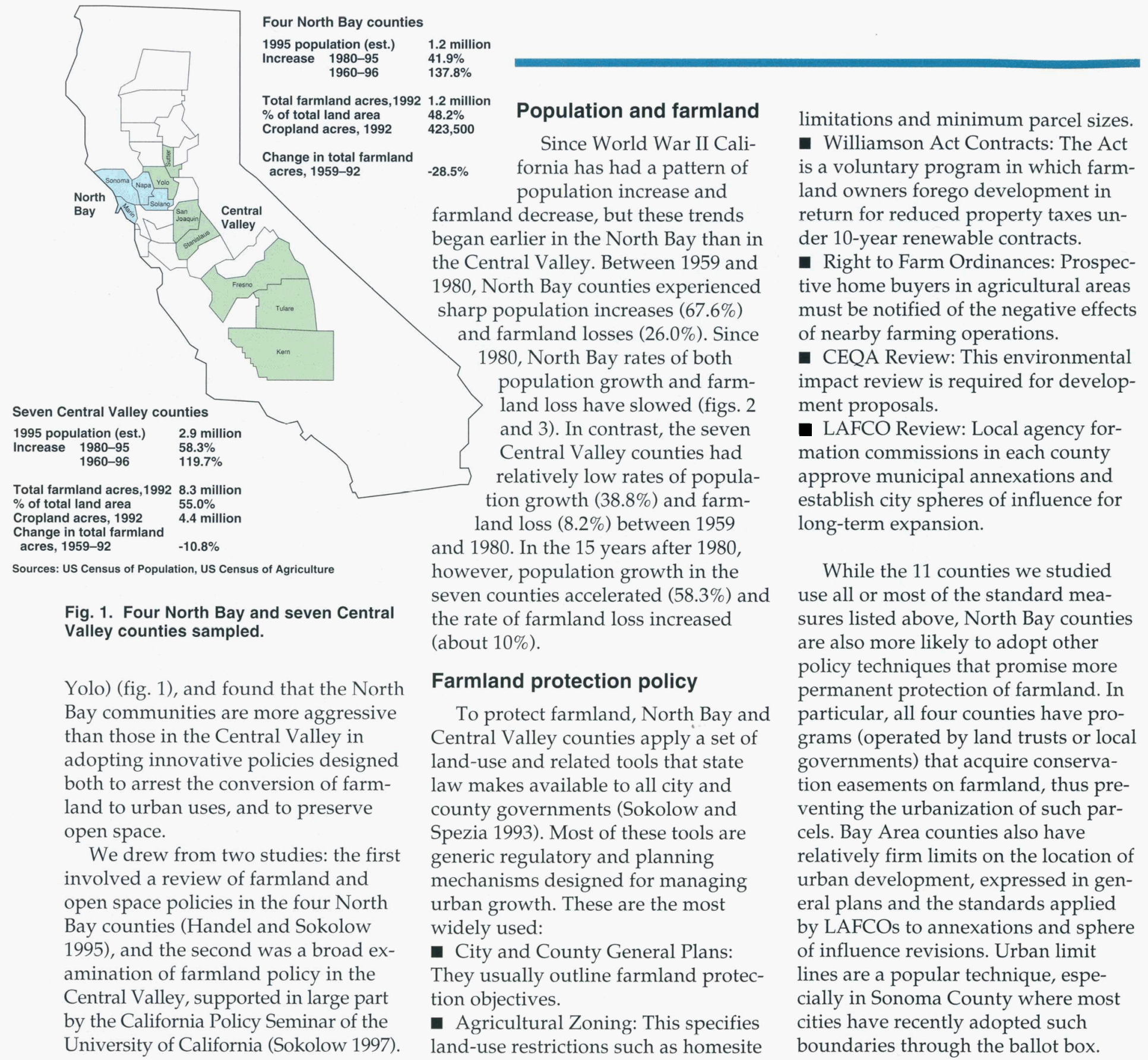

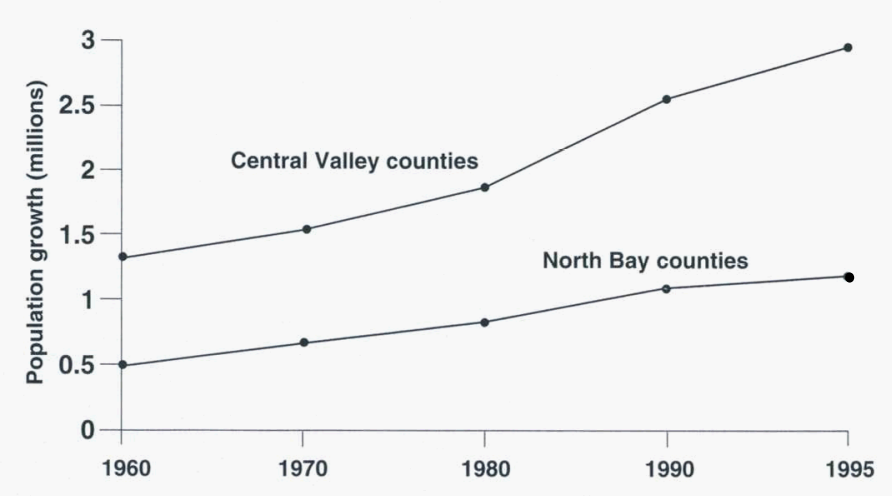

Fig. 2. Population trends in North Bay and sample Central Valley counties, 1960-1995. Source: US Census of Population

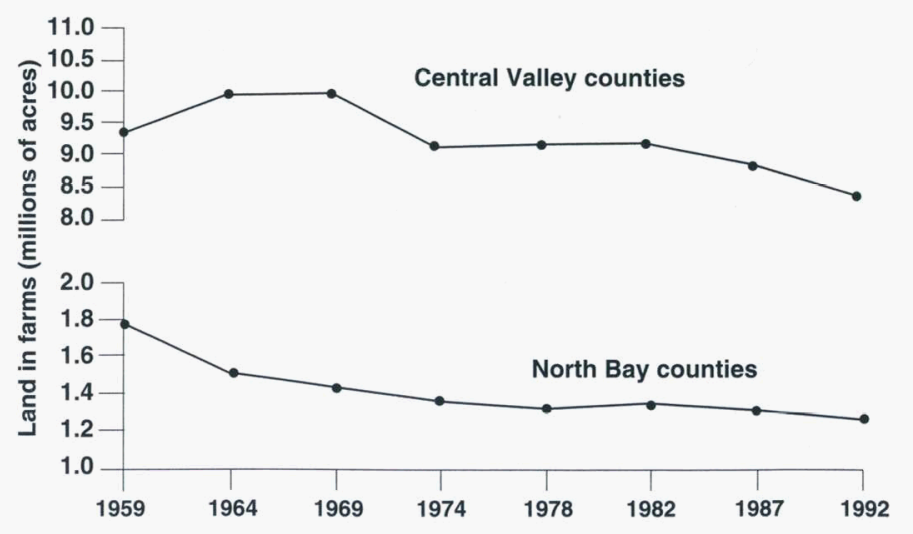

Fig. 3. Farmland trends in North Bay and sample Central Valley counties, 1959-1992. Source: US Census of Agriculture 
Bay Area counties are also more likely to designate large rural areas for agricultural and other open space purposes. For example, in 1973 Marin County identified and continues to protect an inland rural corridor for agricultural and municipal watershed uses (Faber 1994) and in 1968 Napa placed most of its grape-growing valley into an agricultural preserve (Eisele 1994).

Conservation easements acquired in the past 20 years in the four North Bay counties preserve more than 60,000 acres of farmland and other open space (Handel and Sokolow 1995). The easements essentially protect land from urbanization for perpetuity and are typically created either through purchase or donation of the development rights by nonprofit land trusts or local governments (for a comprehensive review of California land trusts, see page 27).

Sonoma County's program is the most ambitious in California and currently the most active local effort in the nation. In 1990 voters approved a quarter-cent sales tax for a 20-year period to fund the purchase of easements and established the Sonoma County Agricultural Preservation and Open Space District to carry out the program. The tax generates almost $\$ 10$ million a year, sufficient to acquire several thousand acres of easements annually.

An older program in adjoining Marin County, the nonprofit Marin Agricultural Land Trust (MALT), has accumulated over 25,000 acres in easements since its founding in 1980.

In contrast, conservation easements are relatively rare in the Central Valley, where they are viewed cautiously due to their permanent nature. We estimate that the entire 18-county region contains only 3,000 to 4,000 acres of farmland in easements, although this preservation method is used more widely for wetlands and habitat protection. Interest in this compensatory technique is growing in the Central Valley, however. Since 1995, the Yolo Land Trust has acquired easements on six farm parcels, totaling 538 acres.
Most are located between the cities of Davis and Woodland and were acquired as mitigation for the loss of other farmland through development in Davis. In 1996 a 1,000-acre easement on productive farmland along Interstate 80 was created by the western Solano County cities of Dixon and

Vacaville to serve as an open space buffer between the two.

\section{Central Valley variations}

While the contrasts between the Bay Area and the Central Valley are striking, there are also significant differences in the ways local governments in the Central Valley deal with the pressures of urbanization on farmland.

Concentrating growth in cities. A major difference concerns the approach of county governments to the location of urban development, especially in relation to farmland in the unincorporated areas they control. Three of the Central Valley counties studied (Kern, San Joaquin and Sutter) are relatively tolerant of development in their areas, including large-lot rural residences. The other four counties studied (Fresno, Stanislaus, Tulare and Yolo) have firm policies that direct growth to cities (table 1). They do not entirely disallow development in unincorporated areas, encouraging growth in existing small population centers. Distinctions also are made between the more "productive" prime or irrigated cropland and other agricultural lands, primarily grazing and dryland crop acres. Tulare County, for example, encourages new development
Many Sonoma County cities have voted to adopt urban limit lines to protect vineyards and other farmland from urbanization.

in its foothills, where relatively poor soils are prevalent.

County-city agreements. Four of the Central Valley counties - Fresno, Stanislaus, Tulare and Yolo - back up their growth location policies with referral agreements with their cities. These agreements allow a city to control developments proposed for the unincorporated fringes near its borders. Generally this means giving the city the option of annexing the property, applying city standards in anticipation of future development, or merely advising the county on appropriate actions.

These referral agreements are given teeth in Fresno, Stanislaus and Yolo counties by revenue-sharing agreements with their cities. The product of tough negotiations, these arrangements allow the counties to share in municipal revenues (including sales 


\section{Central Valley \\ Urbanization in 1993}

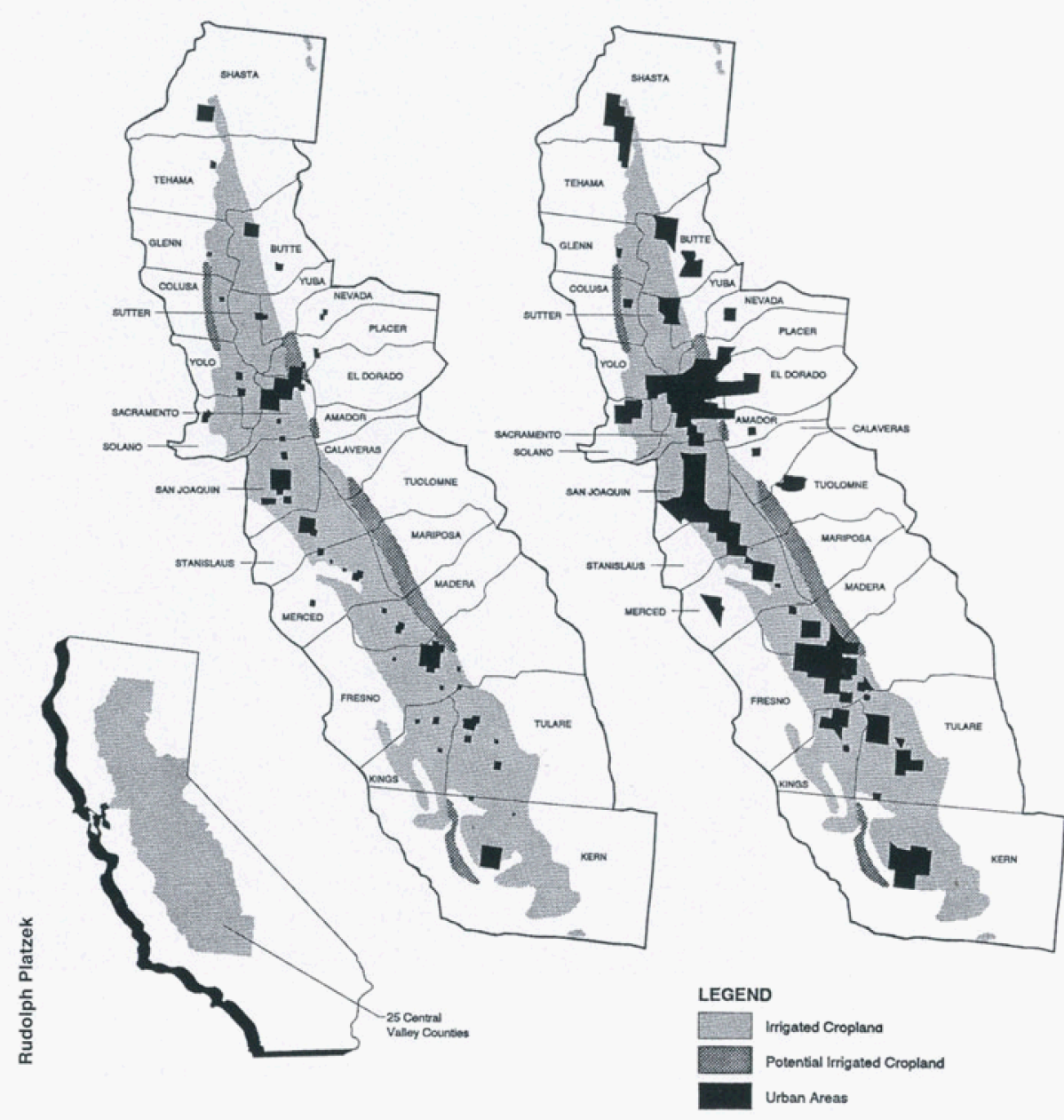

Projected urban expansion on irrigated cropland in the Central Valley.

Retired urban and environmental planner Rudolph Platzek has estimated that, if current growth rates continue, the Valley's population will nearly triple between 1993 and 2040, rising to about 15 million. Sources: Irrigated cropland information from California Department of Water Resources Bulletin 160-83. Urban expansion areas from Alternative Futures for California's Central Valley, Bob Grunwald, September 1993.

taxes, hotel taxes, redevelopment revenues and increased property taxes) in return for not opposing city annexation and referring fringe development proposals to the cities.

Unique policy. Tulare County has a unique policy that stands out as a relatively serious effort to control farmland conversions. It is the only local government in California that regularly applies a precise set of standards to reviewing proposed farmland conversions. Under Tulare's Rural Valley Lands policy, each parcel proposed for rezoning within the county's western third or valley portion is evaluated ac- cording to 13 factors, including soil capability for crop production, parcel size and access to urban services. Depending on the cumulative number of points, a proposal may be rejected outright, automatically approved for rezoning, or subject to the discretion of the board of supervisors.

Adopted as part of the general plan in the early 1970s, the Tulare Rural Valley Lands policy offers a degree of quantitative objectivity that contrasts with the usual subjective processes by which governing boards and planning commissions generally make decisions about farmland conversion proposals.
Over the years, the Tulare point system has clearly reduced the volume of conversion proposals within unincorporated areas: from 1986 to 1993 the county received only 30 conversion proposals concerning a total of only 353 acres with less than 200 acres rezoned for development. During the same period, the adjacent counties of Kern and Fresno each rezoned several thousand acres of farmland for development.

\section{Urban mobilization and ballot box}

More than simply the result of the acts of elected officials and their bureaucracies, farmland protection policies reflect the extent of citizen mobilization and electoral change. Variations in local political scenarios in fact help explain the policy differences between the North Bay and Central Valley counties.

In the North Bay, advocacy of strong farmland and open space policies in the years since World War II originated primarily among urban residents, many of whom are relatively affluent and conservationminded (Handel and Sokolow 1995). A common rallying point for conservation advocates in all four North Bay counties has been the perceived threat of continued population influx outward from San Francisco and other core cities of the Bay Area. Such perceptions are more recent in the Central Valley and so far have not generated the same level of conservation advocacy.

The most important vehicle that North Bay conservationists have used to limit growth is the ballot box. Besides electing conservation-minded candidates to county boards of supervisors, voters enacted open-space measures through initiatives and referenda. Beginning in the early 1970s, each of the four counties adopted major farmland-protection and growthlimiting policies that originated with voter-approved ballot box measures (table 2).

Central Valley counties, by contrast, generally lack such voter-approved 
policies (Glickfeld and Levine 1992). In fact, only three of the Central Valley counties studied have had growthcontrol proposals on their countywide ballots since the 1970s and all were defeated. And no Central Valley community has yet offered its voters a tax increase proposal for acquiring agricultural easements or other open space, such as were adopted in Sonoma and Marin counties.

The Central Valley lacks a regional conservation organization like the Bay Area's Greenbelt Alliance and few of its counties have local environmental groups active on land-use issues. Two exceptions are worth noting. In Yolo County, the Yolano chapter of the Sierra Club operates in unusual cooperation with the local farm bureau to develop mitigation policies for farmland conversions and improve the county's administration of the Williamson Act. In San Joaquin County, the Land Utilization Alliance (an organization of small farmers and environmentalists) frequently criticizes county and city growth policies.

\section{Farm Bureau influence}

Local chapters of the California Farm Bureau Federation and other agricultural organizations are the most influential private interests in initiating new farmland policies in the Central Valley. Local farm bureaus instigated the right-to-farm ordinances adopted by six of the seven Central Valley counties in the late 1980 s and early 1990 s.

The farm bureaus are the principal advocates for farmland protection in Tulare and Yolo counties, which not coincidentally have the strongest farmland protection programs in the Central Valley. Both the Tulare and Yolo Farm Bureaus regularly monitor county planning and land-use decisions. The Tulare Farm Bureau has pushed county officials to refine the innovative Rural Valley Lands Plan (which uses the point system to evaluate rezoning proposals) and has worked with LAFCO to establish firmer standards for city annexation
TABLE 1. Farmland policy emphases by seven Central Valley county governments

Fresno County

Direct urban development to cities. Limit rural residential development to parcels outside nonprime agricultural areas.

\section{Kern County}

As a resource to be protected, farmland is given approximately equal weight to oil and minerals. Allow development in unincorporated areas to provide a range of housing options. Emphasis on landowners' property rights.

\section{San Joaquin County}

Jobs and housing outweigh farmland protection as planning goals; a diminished economic role for local agriculture is projected for the future. No firm policy for directing urban growth to cities. Allow rural residential development.

\section{Stanislaus County}

Direct urban development to cities and to remote areas away from productive soils on valley floor. Allow development in areas with public infrastructure north of Modesto. Limit development in unincorporated areas elsewhere.

\section{Sutter County}

Allow development, including large-lot residences, in unincorporated areas. No policy of directing growth to cities. Emphasis on landowners' property rights. Increased interest now in farmland protection.

\section{Tulare County}

Farmland protection is the principal land-use priority. Direct urban development to cities and to less-productive soils in foothills. Limit rural residential development in unincorporated valley areas.

\section{Yolo County}

Farmland protection and open-space preservation is the principal land-use priority. Direct urbanization to cities; allow some development in unincorporated communities with economic potential. Limit severely rural residential development elsewhere and primarily to farm family members and employees.

Source: General plan language, interviews, newspaper accounts

TABLE 2: Farmland-related measures on countywide ballots in four North Bay counties, 1972-96*

\begin{tabular}{|c|c|c|}
\hline County/Date & Proposal & Result/Yes \% \\
\hline \multicolumn{3}{|l|}{ Marin } \\
\hline November 1972 & Measure A: Property tax for open space district program & Passed \\
\hline June 1992 & $\begin{array}{l}\text { Measure A: Parcel tax to fund open space acquisitions } \\
\text { and farmland easements }\end{array}$ & $\begin{array}{l}\text { Defeated } / 61 \% \\
\text { (req. } 2 / 3 \\
\text { approval) }\end{array}$ \\
\hline November 1992 & $\begin{array}{l}\text { Measure B: Require countywide vote to convert farmland } \\
\text { to urban use (initiative) }\end{array}$ & Defeated $/ 37.2 \%$ \\
\hline November 1996 & $\begin{array}{l}\text { Measure A: Quarter-cent sales tax to fund parks and } \\
\text { open space acquisition }\end{array}$ & $\begin{array}{l}\text { Defeated } / 57.5 \% \\
\text { (req. } 2 / 3\end{array}$ \\
\hline \multicolumn{3}{|l|}{ Napa } \\
\hline November 1980 & $\begin{array}{l}\text { Measure } A \text { : Limits residential development in unincorporated } \\
\text { areas to } 1 \% \text { annual population growth (initiative) }\end{array}$ & Passed \\
\hline November 1990 & $\begin{array}{l}\text { Measure J: Retains agricultural designations in existing } \\
\text { general plan through } 2020 \text { and requires popular vote to } \\
\text { develop in these areas }\end{array}$ & $\begin{array}{l}\text { Passed } / 63.1 \% \\
\text { (initiative) }\end{array}$ \\
\hline November 1992 & $\begin{array}{l}\text { Measure } N \text { : Creates Regional Open Space District } \\
\text { Measure O: Quarter-cent sales tax for district programs } \\
\text { (both initiatives) }\end{array}$ & $\begin{array}{l}\text { Defeated } / 33 \% \\
\text { Defeated } / 29 \%\end{array}$ \\
\hline March 1996 & $\begin{array}{l}\text { Measure } W \text { : Developer-initiated approval for large residential } \\
\text { development-voter approval required under Measure } \mathrm{J} \text { (initiative) }\end{array}$ & Defeated/16.3\% \\
\hline \multicolumn{3}{|c|}{ 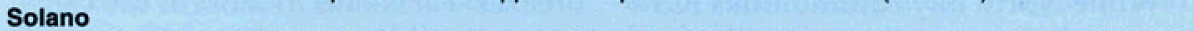 } \\
\hline June 1984 & $\begin{array}{l}\text { Measure A: Prohibits large-scale residential development in } \\
\text { unincorporated areas (initiative) }\end{array}$ & Passed $/ 50.3 \%$ \\
\hline \multicolumn{3}{|c|}{ (2) } \\
\hline November 1984 & $\begin{array}{l}\text { Measure } C \text { : Establishes agricultural production zones and calls for an } \\
\text { easement purchase program (initiative) }\end{array}$ & Defeated $/ 35 \%$ \\
\hline \multirow[t]{2}{*}{ November 1990} & $\begin{array}{l}\text { Measure A: Organizes Agricultural Preservation and Open Space } \\
\text { District (initiative) }\end{array}$ & Passed $/ 70 \%$ \\
\hline & $\begin{array}{l}\text { Measure } C \text { : Quarter-cent sales tax increase to fund easement } \\
\text { acquisitions of district (initiative) }\end{array}$ & Passed $/ 55 \%$ \\
\hline March 1996 & Measure D: Creates 20-year urban growth boundary & Passed $/ 70 \%$ \\
\hline
\end{tabular}

"May not include all countywide ballot proposals during the period, and does not include city measures. Source: Newspaper accounts. 


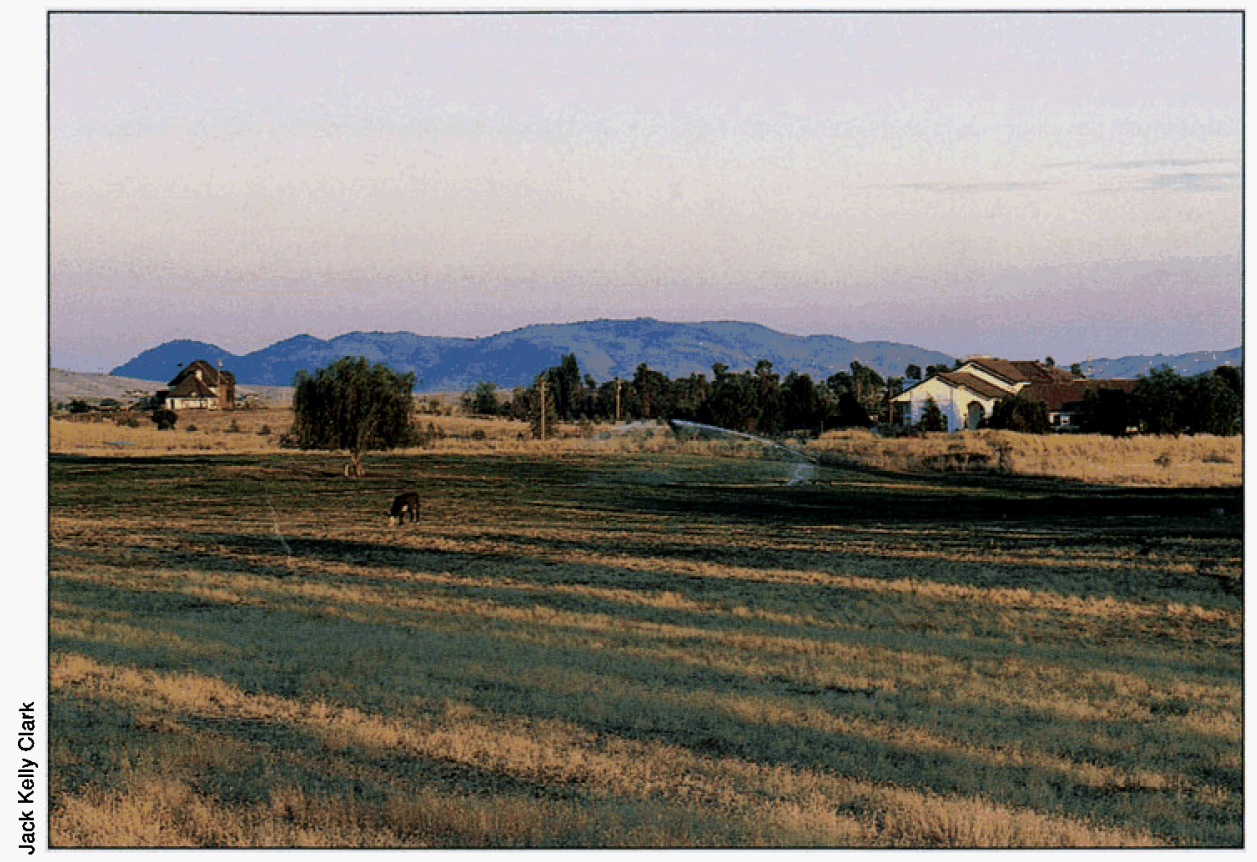

In the Central Valley, an estimated 400,000 acres have been designated for rural residential uses, much of that for large-lot ranchettes.

and spheres of influence. The Yolo Farm Bureau has sought a farmland easement program for its county and has been a prime mover in strengthening Williamson Act standards and revising LAFCO policies to clarify protection standards.

However, in some of the other Central Valley counties studied, the local farm bureaus do not have a common vision of protecting farmlands. Often, the members are divided - some support farmland protection whereas others emphasize more private property rights. Those in the latter group are reluctant to support regulatory measures for fear of restricting future landowner options.

\section{Perceived value of farmland}

While North Bay communities have been more aggressive about preserving farmland in the face of rapid urbanization, it is doubtful that policy lessons from this region can be translated easily and quickly into effective programs in the Central Valley. One reason is that the inland counties generally lack an engaged and organized conservation constituency that promotes successful ballot box measures and supports public funding for easement acquisitions.

Implicit in this regional political difference is a distinction in the perceived value of farmland. North Bay citizens in large part view their remaining farmland acres as an amenity, a form of open space that adds to their quality of life by providing a scenic antidote to urban congestion. By contrast, the prevailing Central Valley perspective is that the region's farmland expanses are primarily an industrial resource. These perceptions undoubtedly reflect the fact that farmland in the North Bay is attractive and appears to be finite, with most of it contained within small, green valleys ringed by soft hills and replenished by ample rain and coastal breezes. Farmland in most of the Central Valley suffers aesthetically by comparison - seemingly endless agricultural acres stretch to the horizon, baked into yellow and brown hues by the summer sun.

It would be erroneous, however, to picture Central Valley communities as insensitive to the farmland conversion problem. Many residents of the region are aware of the projections that esti- mate the conversion of more than a million acres of Central Valley farmland by 2040 under current land-use trends (American Farmland Trust 1995). Local governments there certainly are familiar with the range of policy options for farmland protection; some have adopted far-reaching policies and often reject specific development proposals that threaten agriculture. Whether they can be pushed further in this direction by local circumstances is the critical question for the future of California agriculture. No other areas of the state can support the large-scale farm production that would be displaced by extensive urbanization in the Central Valley.

A.D. Sokolow is Public Policy Specialist, Human $E$ Community Development, UC Davis.

\section{References}

American Farmland Trust. 1995. Alternatives for Future Urban Growth in California's Central Valley: The Bottom Line for Agriculture and Taxpayers. Washington, D.C. Eisele V. 1994. Twenty Five Years of Farmland Protection in Napa County. Faber P. 1994. Marin Agricultural Land Trust: A Case Study.

Froeliger JD, Sokolow AD. 1995. Farmland Protection in the General Plan: A Comparison of Seven Central Valley Counties. Research Paper 2, California Farmland \& Open Space Policy Series. Davis: Agricultural Issues Center, University of California.

Glickfeld M, Levine N. 1992. Regional Growth...Local Reaction: The Enactment and Effects of Local Growth Control and Management Measures in California. Cambridge: Lincoln Institute of Land Policy.

Handel ME, Sokolow AD. 1995. Farmland and Open Space Preservation in the Four North Bay Counties. Research Paper 1, California Farmland \& Open Space Policy Series. Davis: Agricultural Issues Center, University of California.

Sokolow AD. 1993. State Rules and the County-City Arena: Competition for Land and Taxes in California's Central Valley. Publius: The Journal of Federalism 23 (Winter): 53-69 Sokolow AD. 1997. Farmland Policy in California's Central Valley: State, County, and City Roles, CPS brief, Vol 9 (October), California Policy Seminar, University of California.

Sokolow AD, Spezia J. 1992. Farmland Protection Policy. John J. Kirlin, ed., California Policy Choices, Vol. 8. Los Angeles/Sacramento: School of Public Administration, University of Southern California. p. 151-68. 